\title{
Teachers' Pedagogic Competence in Teaching English at Secondary School Level
}

\author{
Nelza Gita Purnama \\ Institut Agama Islam Negeri (IAIN) Bengkulu \\ nelzagita24@gmail.com \\ Risnawati \\ Institut Agama Islam Negeri (IAIN) Bengkulu \\ risnawati.abdul@yahoo.com \\ Detti Lismayanti \\ Institut Agama Islam Negeri (IAIN) Bengkulu \\ dettilis@yahoo.co.id
}

\begin{abstract}
Pedagogical Competence is one kind of competencies that completely need to be mastered by teachers. Pedagogical competence refers to educational and teaching qualifications. One of the qualifications, the teachers should have the ability to manage and run the process of teaching and learning in the classroom. The aims of study are to know how the teacher's pedagogical competence in teaching English. This study used Descriptive approach using mix method and the data were structured observation, questionnaire, and interview. The subjects of this study are an English teacher and 36 students of SMPN 16 Bengkulu Selatan. The findings of this study showed that the pedagogical competence of student is enough in medium category in can be seen at data interview and observation, and supported with the score of students' perception on teachers' pedagogical competence in teaching English were 27.2. The forms include: comprehend the qualities of understudies, this is finished utilizing an individual methodology, learning procedures, learning techniques, and learning materials that suit with students need. For aspects of teacher understanding of learning theory and learning principles which emphasizes very much on manuals, for the parts of educational program advancement educators just comprehend a little about the standards of educational plan improvement. Instructors aggregate schedule and exercise plans dependent on MGP. Based on the results of this study, the researcher suggested to the teachers that they should try to improve their strategy and competence when teaching in the class. The main problem of English Teachers are focusing only on the book instruction, not using English while teaching, and just giving the learners assignments without giving explanation in advance. There are also the solutions of all the problems like joining learning seminar or teacher forum.
\end{abstract}

Keywords: Pedagogical competence, English Teacher, English Classroom, Teaching English. 


\section{Introduction}

The teacher is a person who is very influential in the teaching-learning process, because teacher is a key of successful learning in educational system. According to Evans et al. (2009, p. 4), teacher as educators are members of the community who are dedicated and raised to support education. In addition, the teacher is also a main actor as an educator for the students. Education is nothing meaningful without involvement active of the teacher.

The teacher is a model for their students where everything they do will have an impact on their students. Thus, teacher's attitudes and behaviors are more likely to be imitated by students in the class. In other words, a teacher also carries big responsibilities in his class. Therefore, teachers must really bring their students to the goals they want to achieve because all students depend on them (Martina, et al. 2020). According to Loughran, (2006), as quoted in Wiwi, (2016: 1), said that Being a teacher is not easy as people think, because "teachers play an important role in what they do, and how they do it in developing their own professional knowledge and practices. Moreover, Harmer (2007, p. 57) states have several roles of teacher such as controller, organizing, evaluator, prompter, participant, resource, teacher, and observer. Subhan. (2017, p.64), state that the role and responsibility of teachers in education is very heavy and difficult. Therefore, teachers must really bring their students to the learning goals to be achieved. Teachers must be able to influence their students. Considering this description, it is important for teachers to be competent and professional in their fields.

As a professional, a teacher is a job or activity carried out by someone and becomes a source of income that requires expertise skills that meet certain quality standards or norms and require professional education. Professionals are also characterized by the ability to be honesty. Thus, the characteristics of professional teachers are mastering the material, structure, concepts, and ideas related to the subject, mastering competency standards and basic competencies, developing materials creatively, developing self-professionalism by taking reflective actions, and using information and communication (Republic of Indonesia Regulations Number 16 of 2007 
concerning Teacher Academic Qualification Standards and Attachments to Teacher Competencies).

Based on Republic of Indonesia Regulation No. 14, 2005 concerning coalification, competence and certification, Chapter VI, article 8 state that: 'Guru wajib memiliki kualifikasi akademik, kompetensi, sertifikat pendidik, sehat jasmani dan rohani, serta memiliki kemampuan untuk mewujudkan tujuan pendidikan nasional.", (Teachers must have academic qualifications, competence, educator diplomas, be physically and mentally healthy, and have the ability to realize the goals of national education.)

Based on Republic of Indonesia Regulation No. 14, 2005 concerning coalification, competence and certification, Chapter VI, article 10, verse 1 state that: 'Kompetensi guru sebagaimana dimaksud dalam Pasal 8 meliputi kompetensi pedagogik, kompetensi kepribadian, kompetensi sosial, dan kompetensi profesional yang diperoleh melalui pendidikan profesi." (Teacher competencies referred to in Article 8 include pedagogical competencies, personal competencies, social competencies, and professional competencies obtained through professional education.)

This regulation is similar to Brown (2007, p. 491) that there are characteristics of good language teaching: technical knowledge, pedagogical skills, interpersonal skills, and personal qualities. These characteristics are shown in the preparation, presentation, implementation or method of the teacher, personal characteristics, the interaction of the teacher and students. The teacher's role is the role of a "critical educator" which serves to highlight the fact that the teacher is not just a language teacher. A teacher is more than that (Brown, 2001, p. 443) because the teacher is an agent of change in a world that is in dire need of change.

However, knowledge about how to be a good teacher is not enough to make the teacher able to teach well. They also need to have teaching skills or pedagogical competence (Hotaman, 2010). In addition, Indonesian Government Regulation No. 74, 2008 about Teachers defines that teacher pedagogical competence is the ability of teachers in the management of student learning. Competence pedagogic is a special competency that differentiates teachers from other professions (Jahiriansyah et.al., 
2013; Retnowati, 2013) which shows the ability of teachers to organize learning material so that it can be easily understood by students. In addition, a good teacher is the most determining students' achievement in class (Hayes, 2003: 54). So, students' achievement is seen from how teachers master all teaching abilities. Then, having basic skills is one of the most important aspects of being a good teacher. This can help them to develop and describe the courses and methods explicitly.

Besides that, the teachers are required to be more progressive than students and they must also have more knowledge about things that will be explained by teachers to their students (Livia, 2010: 1). The teacher can be called competent teachers if they have good competence and performance. That is because both are two important factors that EFL teachers need to implement successful classroom instruction (Brown, 2001). Therefore, the study of teachers, competencies and performance in language teaching has become an important aspect of effective teaching in every school.

The success of teaching and learning process is not just about whether the teacher using English or not. However, the teachers' knowledge of learning method is also an essential thing to be mastered. In fact, only few of English teachers who figure out what the teaching method actually is. This problem still find in many school in Indonesia especially in rural area. Based on research observations from one of the schools in Bengkulu province especially in South Bengkulu regency that is SMPN 16 Bengkulu Selatan, There are some troubles that are being faced by the English teacher in giving English materials in the class. The main problems are: not using English while teaching; not using appropriate method, focusing only on the book instruction, and just giving the learners assignments without giving explanation in advance.

\section{Literature Review}

\section{English Teacher}

Webster outlines English is the characteristic of England, the English people, or the English language. Oxford dictionary (2011) explains teacher is a person whose job is teaching, especially in a school. In agreement with Indonesian Dictionary (2015) mentions a teacher is the one who works for teaching. Meanwhile, Murray potrays 
(2009) a teacher is learning symbol; a leader of learners and a miracle to education. Yet, Brown (2017) states that the teacher is an agent of change in a world that is in dire need of change. According Act number 14 of 2005 article 1, paragraph 1 (Dalam UU nomor 14 tahun 2005 pasal 1, ayat 1) states Teachers are professional educators with the primary task of educating, teaching, guiding, directing, train, assess and evaluate students on early childhood education, formal education, primary education and secondary education.

Furthermore, Gill describes English teacher is working in subject-specific classrooms in middle and high school, junior colleges and universities and they may specialize in a specific area like English competition. Therefore, the researchers concluded that an English teacher is someone who has the ability of English and has the ability to guide, direct, teaches English to students in the classroom.

\section{Pedagogic Competence}

Pedagogical Competence is one kind of competencies that completely need to be mastered by teachers. Basically, according to Susilo (2011: 115), pedagogical competence is the capability of teachers to manage the education of students, include: setting up the learning device, implementing the learning, and evaluation. Other hand, in dictionary of education, pedagogic competence is " The theory and practice of teaching children, which includes the philosophy, sociology, psychology and methodology involved in teaching children as well as curriculum, school organization and management.

In addition, according to Ryegard, et.al (2010), pedagogical competence refers to educational and teaching qualifications. One of the qualifications, the teachers should have the ability to manage and run the process of teaching and learning in the classroom. The flow of interaction, teachers' performance, the ability to design a lesson plan, the appropriateness in choosing the method and media of learning also become the indicators of pedagogical competence (The Law No. 14 of 2005). This opinion is corresponding to the Rule of the Government No, 19/2005 about the National Education Standard pasal 28 , ayat 3 who explain that pedagogic competences is the ability to manage the teaching learning process includes the understanding of learners, lesson 
Jadila: Journal of Development and Innovation

in Language and Literature Education

Publisher: Yayasan Karinosseff Muda Indonesia
E-ISSN: 2723-6900

P-ISSN: 2745-9578

Volume 1 Number 32021

Page: $362-376$

design of learning, evaluation of learning outcomes, and the development of learners to actualize their competence.

From some definitions above, the definition of pedagogic competence in this research is a set of mastery of abilities, skills, values, and attitudes that must be owned, lived, and controlled by the English teacher that come from education and experience that can perform their teaching duties in a professional manner in teaching and learning process.

Based on The Regulation of Teacher's Academic Qualification Standard and Teacher's Competence (UU RI No. 16/ 2007) includes ten indicators namely: Mastering learners' characteristics from the physical Aspect, Moral, and spiritual, Social, Cultural, Emotional, and Intellectual. Mastering the theory of learning and the principles of educated learning; Developing the curriculum associated with the lessons; Conducting educated learning; Utilizing information and communication technology for learning, Facilitating learners' potential to actualize their potential; Communicating effectively, empathic, and polite with learners; Conducting the assessment, the process evaluation, and the learning outcomes; Utilizing the results of assessment and evaluation for learning, Doing a reflective action to improve the quality of learning.

\section{Research Method}

The Study designed used by the researcher is descriptive method. It is being qualitative and quantitative approach by using descriptive design. This Study has been completed done in one of Junior High School in Bengkulu Province. This school is SMPN 16 Bengkulu Selatan.

The subjects of this study are an English teacher at Second Grade of SMPN 16 Bengkulu Selatan and 36 English Students. The instrument which was used by the researcher in collecting the data is interview, observation and questionnaire. The data gained from the result of interview, observation, and questionnaire is analyzed through Model of Data Analysis Miles \& Huberman and Likert Scale. 


\section{Results and Discussion}

\section{Teacher competence in teaching English}

on the result of interview found the data that teacher tried to be professional teacher to manage their classroom such as using method that appropriated with a lesson; using approach to know how the students' characteristics, giving some task to know enhancement, and giving evaluation and assessment. But there are difficulties that teacher found such as students do not follow lessons well, there are also students who are lazy to do assignments, and there are students who difficult to understanding the material. Teacher as educator and facilitator in education must to have many way or strategies to resolve problem that they faced in classroom. They also should know how to understanding characteristic of student, because students do not have the same abilities. E. Mulyasa (2003: 53) stated that Educators must have academic qualifications and competencies as learning agents, be physically and mentally healthy, and have the ability to realize the goals of national education. Teacher also must to be professional and competence in manage their class effectively in order to reach the goal of learning.

Based on the results of the interview, it was known that the teacher used an individual approach to understand the characteristics of each student. It is important to teacher in understand how characteristic students in class, with this approach can made the teacher understood what the level of students' difficulty in received the material in learning process, because every students is different. According to Djamarah (2005: 59): "There are several approaches expected from the teacher, namely: 1) an individual approach, 2) a group approach, 3) a varied approach, 4) an educational approach. Individual approach is an approach taken by the teacher towards students that aims to guide and help students individually. In this approach the difference in student character is an important thing that must be considered, in order to achieve completeness in student learning." The approach taken by the teacher to understand the character of students is good, by applying the individual approach; the teacher can guide and help 
students in the learning process. However from the result of classroom observation showed that English Teacher have not done some aspects in delivering the benefits of learning materials, presenting the lesson objectives, providing motivation associated with the material being studied, and delivering learning activities plan. So, it was not proved that the teachers mastered learners' characteristics from the physical aspect, moral, spiritual, social, cultural, emotional, and intellectual because a teacher who has not known the characteristic of learners, the teacher could not do the aspects mentioned above.

Based on result of interview, the researcher found the data that teacher apply student's center approach where the system of learning focused on students. "Dalam Permendikbud No. 81A tentang Implementasi Kurikulum 2013 menyatakan bahwa Student Centre Learning merupakan pendekatan Pembelajaran Kurikulum 2013”. "From Permendikbud No. 81A about the implementation of curriculum 2013 said that Student Centre Learning is an approach of learning 2013." So it can be said that the approach that teacher of SMPN 16 Bengkulu Selatan applied in accordance with the 2013 Curriculum where learning is focused on students. In students center approach the teacher usually teach with using presentation and group discussion, after that give some task for students to discuss it. As Brown (2001, p. 430) said, there are other methods like discussion, so it stimulates interaction, cooperation, and teamwork in the classroom. However from observation result the researcher found the data that the teacher still using lecture method at most and still focused on book instruction. It mean that the teacher have not implementation the method that appropriated with curriculum used. As Dimayanti and Mudjiono (2008:37) said that there are some aspect of teacher's role in learning process, and one of them is the teacher should carry out learning appropriate with various model of learning that appropriated with student's condition, learning materials, and the condition of school. From explained above the teacher should professional to choose what method that suitable with the lessons, characteristic of students or students' need, and school's condition.

Based on the result of interview found the data that teacher just follow directive from the regulation of school use to develop curriculum, and development of 
Jadila: Journal of Development and Innovation

in Language and Literature Education

Publisher: Yayasan Karinosseff Muda Indonesia
E-ISSN: 2723-6900

P-ISSN: 2745-9578

Volume 1 Number 32021

Page: $362-376$

curriculum and material are taken from syllabus and textbook. It is mean that the teacher just a little understand about the principles curriculum development. It proves that in developing the curriculum and material, teachers should take a look again to the Regulation of Teacher's Academic Qualification Standard and Teacher's Competence (UU RI No.16/2007). It because as an educator, teacher should understood how curriculum development in the school system based on regulation.

Based on interview the researcher found the data that the teacher develop syllabus and lesson plan based on MGP (Musyawarah Guru Mata Pelajaran). After that, the teacher investigated the syllabus and lesson plan based on students' need in the school. The syllabus and lesson plan should be appropriated with the curriculum. Based on the provisions of the law above it can be said that the teacher has tried to improve teacher professionalism, among others, it can be done through training activities, research, writing scientific papers, and other professional activities. The activity is Musyawarah Guru Mata Pelajaran (MGMP). The teacher should make lesson plan and syllabus appropriated with students' need and students' ability. It is similar with Dimyanti and Mudjiono (2008:37) that is the teacher should make lesson plan in a written, complete, and comprehensive. Based on explained above it can be concluded that teacher can develop lesson plan and syllabus that appropriated with students need.

Based on interview the researcher found the data that media used by the teacher is visual media. The teachers used picture as a media to help the students know every meaning of the question or new vocabulary. Sometimes the teacher used audio visual media as video if it enables to use. However, the teacher said that he still has many obstacles in using instructional media / ICT in the learning process due to the lack of facilities at school. It because this school still in rural area. Suryana (2013, p. 24) concludes that ICT-based learning teaching on the curriculum is required and needed to be applied in the teaching-learning process. In fact, based on the result of classroom observation, English teacher not always used sources/media in learning. Those are the aspects that can be related to the information and communication technology for learning. This is due to insufficient facilities at school to continue using ICT. The teachers just use blackboards and textbooks. The teachers is required to know more 
Jadila: Journal of Development and Innovation

in Language and Literature Education

Publisher: Yayasan Karinosseff Muda Indonesia
E-ISSN: 2723-6900

P-ISSN: 2745-9578

Volume 1 Number 32021

Page: $362-376$

about this point because adapts textbook material adding by other audio, visual, and mechanical aids creatively is very useful as Brown states in 2001 (p. 430). So, it can be concluded that teacher only uses ICT if possible or it can be said that teacher not using the media all the time even though the material taught requires ICT as a support.

Based on the result found the data that teacher gives the student opportunity to follow competition to developing the learners' potential of students. It proves that teachers must be able to act as a facilitator, motivator, and mentors who give more opportunities to students to seek, cultivate own information, and also follow some competition (Uno, Hamzah 2006). Based on Law No. 14 of 2005, explicitly stated that teachers are professionals who are obliged to always uphold the Teacher Code of Ethics, so that the honor and dignity of teachers in carrying out their professional tasks can be maintained. The Teacher Code of Ethics contains a set of moral principles and norms that underlie the implementation of professional duties and services of teachers, in accordance with religious, educational, social, ethical and humanitarian values. The main task of the teacher is trying to develop all the potential of their students optimally, so that they can be independent and develop into intelligent people, both physically, intellectually, socially, emotionally, morally and spiritually. Based on the provisions of the law above, it can be said that the teacher has tried to improve and provide a forum for students to develop the potential of students, namely in the intellectual aspect, although teachers should also pay attention to other aspects. English teachers think that effective communication in teaching is using Indonesian-English mixed because students would not understand if the teachers use English full. It is because the location of the school still in rural area where the language uses in daily is regional language. So that way this is the best way to make a good communication with the students so that there is no misunderstanding between teacher and students. It was also showed in the classroom observation that teachers did not use the right language that was English. But, based on the theory of Maxom (2009, p. 9), even though students inevitably speak in their mother tongue from time to time, teacher can respond in simple English, with gestures or pictures. 
Based on the result the researcher found the data that the teacher did three kind of evaluation such as: first, in each subject or formative test. Second, the evaluation that did in middle of semester or MID Semester evaluation. Last, the evaluation that did in the last of semester called last exam. As according to Assessing Arikunto (2009), Evaluation is taking a decision on something with a good measure of bad. Assessments are qualitative. Assessment is done after measuring. The teacher has implemented an assessment that functions to find out and monitor student progress both in the process, progress and student learning outcomes. Other hand, Harmer (2001, p. 321) states that there are placement tests, diagnostic tests, and progress or achievement test. The teachers have not done placement tests. Teachers have done diagnostic tests by formatif test. The last, teacher used midterm test and final test for deciding students' progress and students' achievement. The teacher uses the results of assessment and evaluation for giving more attention to students who have less ability in English like giving remedial. The results of assessment also used for filling the contents of students' report book. This also related to Harmer (2001, p. 321) that there are placement tests, diagnostic tests, and progress or achievement test. Those are useful for the teachers because this indicator is about utilizing the results of assessment and evaluation for learning.

\section{Students' Perception on Teachers' Pedagogic Competence}

\begin{tabular}{|c|c|c|c|c|}
\hline \multirow{2}{*}{$\begin{array}{c}\text { No } \\
\text { Question }\end{array}$} & \multicolumn{5}{|c|}{ Percentage of Question Answer (\%) } \\
\cline { 2 - 5 } & Strongly Agree & Agree & Sometimes & Never \\
\hline $\mathbf{1 .}$ & 19.5 & 33 & 44.5 & 3 \\
\hline $\mathbf{2 .}$ & 58 & 36 & 3 & 3 \\
\hline $\mathbf{3 .}$ & 19.5 & 25 & 44.5 & 11 \\
\hline $\mathbf{4 .}$ & 14 & 19 & 28 & 39 \\
\hline $\mathbf{5 .}$ & 22 & 25 & 128 & 25 \\
\hline $\mathbf{6 .}$ & 17 & 33 & 50 & - \\
\hline $\mathbf{7 .}$ & 30.5 & 55.5 & 8 & 6 \\
\hline
\end{tabular}




\begin{tabular}{|c|c|c|c|c|}
\hline 8 & 14 & 19 & 42 & 25 \\
\hline 9. & 47 & 25 & 17 & 11 \\
\hline 10. & 44 & 25 & 17 & 14 \\
\hline 11. & 39 & 41 & 14 & 6 \\
\hline 12. & 22 & 28 & 39 & 11 \\
\hline 13. & 33 & 53 & 14 & - \\
\hline 14. & 11 & 17 & 47 & 25 \\
\hline 15. & 22 & 36 & 39 & 3 \\
\hline
\end{tabular}

Percentage of mean score of students' perspective of teacher's pedagogic competence

\begin{tabular}{|c|c|c|c|}
\hline NO & $\begin{array}{c}\text { ITEM } \\
\text { QUESTION } \\
\text { SCORE }\end{array}$ & $\begin{array}{l}\text { KRITERIUM } \\
\text { SCORE }\end{array}$ & $\begin{array}{c}\text { PERCENTAGE } \\
(\%)\end{array}$ \\
\hline 1 & 97 & \multirow{15}{*}{144 (4 X 36) } & $67 \%$ \\
\hline 2 & 126 & & $87.5 \%$ \\
\hline 3 & 91 & & $63 \%$ \\
\hline 4 & 76 & & $52.8 \%$ \\
\hline 5 & 88 & & $61 \%$ \\
\hline 6 & 96 & & $66.7 \%$ \\
\hline 7 & 112 & & $77.8 \%$ \\
\hline 8 & 80 & & $55.6 \%$ \\
\hline 9 & 111 & & $77 \%$ \\
\hline 10 & 108 & & $75 \%$ \\
\hline 11 & 113 & & $78.5 \%$ \\
\hline 12 & 94 & & $65 \%$ \\
\hline 13 & 115 & & $79.8 \%$ \\
\hline 14 & 77 & & $53.5 \%$ \\
\hline 15 & 100 & & $69.5 \%$ \\
\hline $\mathrm{N}=15$ & JUMLAH & & $408 \%$ \\
\hline & RATA-RATA & & $27.2 \%$ \\
\hline
\end{tabular}

Based on mean score about students' perception on the English teacher pedagogic competence in teaching English was 27.2 including medium category. According to Sujanto (2009: 30) Perception is a process that is preceded by sensing. It is 
Jadila: Journal of Development and Innovation

in Language and Literature Education

Publisher: Yayasan Karinosseff Muda Indonesia
E-ISSN: 2723-6900

P-ISSN: 2745-9578

Volume 1 Number 32021

Page: $362-376$

a process of tangible receipt of stimulus by the individual by means of its receptor. Then the stimulus was forwarded to the central nervous system, the brain, and there was a psychological process so that the individual is aware of what he saw, heard and so forth. According to the explanation above, the researcher would like to define more about students' perception. It is mean that a respond of someone to recognize object, quality, preceded and event by sensing the response of sensory then relayed to the brain, and then going on processes of psychological, so that people can understood the experienced. A student in the general impression is that every person who accepts the influence of a person or people group who operate education. Thus, the perception of students is the response or acceptance of the students. It is a direct response in interpreting what is captured through the senses by students. Based on the results of the research, the students' perceptions of pedagogic ability of English teacher that taught in class VIII A-C has pedagogic ability that was in the medium category. It shows that English teacher still should be increase the competence in teaching

\section{Conclusion}

Based on discussion above, it can be concluded that; an analysis of Teachers' Pedagogic Competence in Teaching English was in category enough from the result of interview and observation in teaching English at the second grade students of SMPN 16 Bengkulu Selatan.

The data of interview and observation are supported with students' perception on the teachers' pedagogical competence with mean score 27.2 in medium categories. The data also supported with data documentation such as syllabus and lesson plan, the teacher actually has tried to make class running good. Although the teacher still have to increase and repair the quality of learning process in order to excellent.

From the conclusion above, the researcher have several suggestions such as: First, the student should follow the process of learning well in order to understanding the material that delivered by teacher. Second, the teacher should be creative in conveying the materials to students. It is mean that the teacher should know what are the strategies, methods and learning media who appropriated with characteristic and abilities of the 
students. Third, the teacher should give a reword for students so that the students more enthusiasm to following the learning process. Fourth, the teacher can follow coaching to improve their capability.

\section{Reference}

Afidburhanudin. (2013). Pengumpulan data dan instrument penelitian. Dalam website Https://afidburhanudin.wordpress.com/2013?05?21/penumpulan-data-data-daninstrument-penelitian. Diakses pada 23 January 2019.(online

Andreia., \& Liliana. (2011). Pedagogical competences -The Key to Efficient Education. International Online Journal of Educational Sciences.pdf

Barizi, A. (2009).Menjadi guru unggul. Yogyakarta: Ar-Razz Media

Arikunto. (2013). Manajemen penelitian. Jakarta: PT. Rineka Cipta

Badan Standar Pendidikan Nasional. (2006).Retrieved on October $10^{\text {th }} 2017$. From www.bsnp-indonesia.org/id/wp-content/uploads/2012/04/laporan-BSNP2010.pdf.

Brown, D. (2007). Teaching by Principles an interactive approach to language pedagogy. New York: Person Longman, San Francisco State Univer.

Brown, D. (2001). Teaching by principles an interactive approach to language pedagogy. New York: Person Longman, San Francisco State Univer.

Cece, W. (1992). Kemampuan dasar guru dalam proses belajar mengajar. Bandung : PT Remaja Rosda Karya.

Darmadi, H. (2015). Tugas, peran, kompetensi, dan tanggung jawab menjadi guru Profesional. Pontianak: IKIP PGRI.

Depdikbud. (1997). Kamus besar bahasa Indonesia. Jakarta: Balai Pustaka.

Dimyati., \& Mudjiono. (2008) Belajar dan pembelajaran. Departemen pendidikan \& kebudayaan. Rineka Cipta.

Evans, D., Tate, S., Navarro, R., \& Nicolls, M., (2009). Teacher education and professional development in Indonesia. Aguirre Division of JBS International.

Frengkel., Jack, R., \& Norman, E, Wallen. (2009). How to design and evaluatebresearch in education. New York. McGraw-Hill Companies.

Hamer, Jeremy. (2001). The practice of English language teaching. Third edition. Longman person Education limited.

Hayes, C. (2003). Teacher professional development: A Primer for Parents and Community Members.

Livia, T. (2010). Teachers' thought of their academic background and professional development. Unpublished M. A. Thesis, Jakarta: Atma Jaya Catholic University of Indonesia.

Lodico., Marguirite, G., Dean, T., Apaulding., \& Katherine , H. Voegetle. (2010). Method Educational Research. San Fransisco: Jose Bass.

Martina, F., Syafryadin, J. S., \& Rakhmanina, L. (2020). Novice teacher's pedagogical content knowledge (PCK) in teaching English for young learners. Journal of Critical Reviews, 7(14), 1472-1476.

Moleong. (2008). Metodelogi Penelitian Kualitatif, Bandung:PT Remaja Rosdakarya. 
Mulyasa. (2012). Standar Kompetensi dan Sertifikasi Guru.Bandung;Remaja Rosdakarya.

Nurfadillah, R. (2015). Pedagogical competence of English teachers with non-English educational background in Kuningan Regency: Problems and solutions. Indonesian EFL Journal, 1(2).

Hamalik, Oemar. (2008). Kurikulum dan pembelajaran, Jakarta: Bumi Aksara.

Oxford. (2007). Concise Oxford English Dictionary. England: Oxford University Press.

Siti, Muhimatul., \& Dwi. (2017). Building Teacher's Pedagogical Competence and Teaching Improvement through Lesson Study. Arab World English Journal (AWEJ).

Subhan. (2017). The pedagogy of teaching English to young learners: Implications for teacher education. Indonesian Journal of English Language Teaching.

Sugiyono. (2010). Metode Penelitian Pendidikan Pendekatan Kuantitatif, kualitatif, dan $R \& D$. Bandung: Alfabeta.

Susilo. (2011). Perencanaan Pembelajaran. Bandung : Remaja Rosda Karya.

Thomas, M. Risk. (1974). Principles and Practices of Teaching In Secondary School, 2 ed. American Book Company.

Undang-undang Republik Indonesia Nomor 14. (2005).Tentang Guru dan Dosen. Jakarta: PB PGRI.

Undang-undang No. 20 tentang Sistem Pendidikan Nasional Tahun 2003

Uno,. \& Hamzah, H.B. (2007). Profesi Kependidikan: Problema, Solusi, dan Reformasi Pendidikan di Indonesia. Jakarta: Bumi Aksara.

Wiwi. (2016). An Analysis of teachers' pedagogical competence in teaching English for young learners. Cirebon

Wiersma, W. (1986). Research method in evaluation: An Introduction. Massachusetts: Allyn and Bucon,Inc. 